\title{
Creating the global library of the future
}

\author{
Highlights from the 66th IFLA Conference
}

\author{
by Hannelore Rader
}

F rom August 13-18, 2000, the International Federation of Library Associations (IFLA) held its 66th conference in Jerusalem, Israel. Approximately 1,500 delegates from 93 countries attended the conference with the theme "Information for Cooperation: Creating the Global Library of the Future," an appropriate theme as we enter the next millennium and try to prepare the global library of the future.

It was the first time that IFLA in its 73 years of existence held the annual conference in the Middle East. Unfortunately, the Palestinian librarians and most of the Arab countries chose to boycott.

The largest delegation, 296 delegates, was from the host country, Israel, and the second largest group, 247 delegates, was from the United States. More than one hundred exhibitors presented their various products and demonstrations during several days of the conference. As in previous years, the ALA booth was most popular, with conference attendees who stopped to pick up literature about our professional organizations and to chat with ALA dignitaries. More than 50 committee meetings and more than 100 programs were held, addressing topics such as:
- exchange of electronic bibliographic data,

- crosscultural networking partnerships,

- multicultural Internet,

- management of information,

- onsite libraries and virtual libraries,

- educating the professionals for the global information infrastructure,

- reading in the digital society, and

- preservation of the past for the future.

All programs were translated simultaneously into five languages: English, French, German, Spanish, and Russian.

At Council I of the conference, the membership voted to approve the revisions of IFLA's statutes, including a banded, differentiated fee structure.

The keynote speaker at the opening session was Shlomo Aveneri, professor of Political Science at Hebrew University, author of several books on political science, and an experienced politician from Israel.

Christine Deschamps, president of IFLA, addressed conference participants by summarizing the past year's activities and her work with the Council to help IFLA develop a more democratic structure to prepare the association for the needs of the 21st century. Change is necessary to ensure that IFLA con-

\section{About the author}

Hannelore Rader is university librarian at the University of Louisvilie and'ALAIACRL Representative to IFLA University and General Research Libraries Standing Committee, e-mail:h.rader@louisville.edu 
tinues to be viable and productive as an organization. This year a major focus of IFLA was the training of professionals, or as many people call them, different types of knowledge workers. Helping developing countries with their libraries is another goal of the organization and a variety of projects are in place, including a revision of the dues structure to enable these countries to participate more.

Other guest lecturers were Meir Shalev, one of Israel's most celebrated young novelists and columnist; Yair Zakovitch, professor of Bible at Hebrew University; G. Y Baklavov, a Russian writer who is working on creating and establishing a new democratic society in Russia; and Steven Shrybman, a lawyer from

Canada. These speakers addressed diverse topics in the global environment from politics, economics, and religion to literature.

Thirty-one poster sessions were presented, including many topics such as lifelong learning, digitization, Web information seeking, library in-

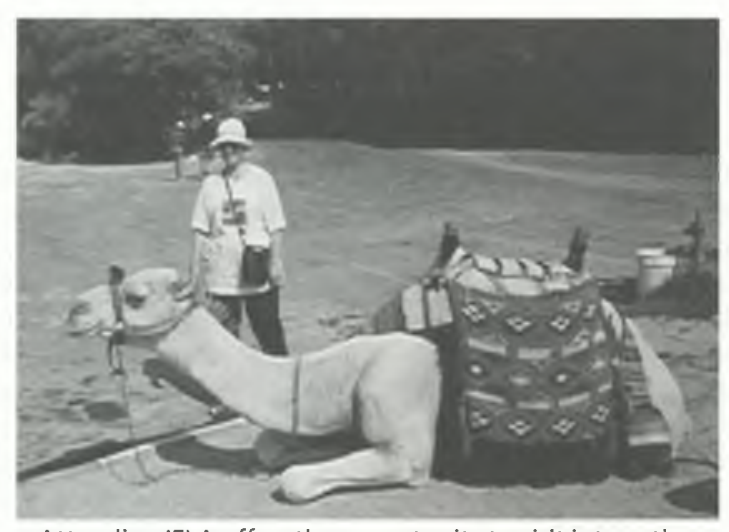

Attending IFLA offers the opportunity to visit interesting places. Here Hannelore Rader checks out the camel transport. struction in an international setting, library services to children, and many others.

The User Education Roundtable held a workshop at Hebrew University's Mt. Scopus campus entitled "Training the Information User for the Global Library of the Future." Speakers from Hebrew University, Israel, Mexico, and South Africa spoke about information competencies and the diversity in training students for information use.

IFLA's University Libraries and General Research Libraries Standing Committee, the largest committee within IFLA with a membership of more than 473 , sponsored the following programs.

\section{Benchmarking and best practice}

Presentations and discussions continued to address performance measure in the elec- tronic environment and how to use benchmarking to measure performance. German. Australian, and British libraries are beginning to use benchmarking to measure performance. A Handbook on Cost Analysis by Roswitha Poll of Muenster, Germany, will be published soon

\section{Raising the profile}

"Raising the profile of academic libraries and librarians" addressed marketing academic libraries beyond the university campus as part of a campus-wide strategy, provided strategies for raising the profile of academic libraries, and discussed developing a marketing plan. 


\section{Another view from the conference}

It was my great pleasure to serve as a first-time delegate to the 66th General Conference of IFLA, and to serve as the liaison to IFLA on the New Members Round Table of ALA. IFLA is a federation of library associations, thus IFLA members might typically be bodies such as ALA, the Library Association of the United Kingdom, or the Association of Christian Librarians.

Delegates at the IFLA conference included the entire IFLA headquarters staff, traveling from The Hague, Netherlands, directors of national libraries from all over the world, international, and national library association members of IFLA, institutional members of IFLA, and personal affiliates (individual members) of IFLA such as myself.

\section{What was the conference like?}

If you have been to an ALA Midwinter Meeting, that is what it was like: mostly meetings (of sections and round tables), with relatively few programs to attend. In addition, the conference sponsored two outings in Jerusalem: an outdoor dinner social on the campus of Hebrew University and a museum trip and reception at the Israel Museum. I was also able to do some sightseeing, taking tours to the Old City of Jerusalem, to sites in the New City, and to the town of Bethlehem.

I am indebted to and would like to thank ALA for selecting me as the recipient of this year's award from the Bogle/Pratt International Library Travel Fund, a grant from ALA's International Relations Committee to enable a librarian who is a member of ALA to attend his or her first international conference.

For further information on the Bogle/ Pratt International Library Travel Fund, see the AI.A awards, grants, and scholarships Web page at http://www.ala.org/work/ awards/index.html.-Penelope Papangelis, Western Kentucky University Libraries, penny.papangelis@uku.edu academic librarians throughout the world. From the many discussions it is apparent that most of our academic library issues are shared with academic librarians throughout the world. ${ }^{1}$

A number of cultural events sponsored by the conference featured such sites as Hebrew University and the Israel Museum, holding the Dead Sea Scrolls. Hebrew University was founded in 1918 and opened in 1925 , awarding its first degrees in 1931. It is now a well-established teaching and research institution with 23,000 students and a beautiful setting on top of Mount Scopus. Its library features 735,000 volumes, 37 librarians, and 8,000 users a day.

\section{The city}

Jerusalem is a fascinating city, filled with historical and religious sites of enormous interest to most visitors. The old city, the markets, and the religious and historical sites are impressive. Being in the Holy Land and seeing such famous locations as Bethlehem, Nazareth, the Sea of Galilee, the Dead Sea, the Jordan River, and Jericho was an unforgettable experience.

\section{Note}

1. Many of the IFLA papers resulting from the programs will be available on the IFLA site http://www.ifla.org.

\section{New From ACRL; Library Web Site Policies, CLIP Note \#29}

Jeri Traw, compiler

Typical issues addressed are use/standardization of headers and footers; navigational elements; date files are updated; format/type of information to include; indication of page authorship, submission and contribution procedures, proofreading for errors, testing prior to uploading, browser compliance, and server access. Selected bibliography. 0-8389-8088-0, \$25.00; ACRL member $\$ 22.50,104 p$., 2000

To Order, write: ALA Fulfillment, 155 N. Wacker Drive, Chicago, IL 60606, call: $800-545-2433,($ press 7$)$, or fax: $312-836-9958$ 